\title{
The Role of Emotion in Product, Service and Business Model Design
}

\author{
Karla Straker ${ }^{1}$, Cara Wrigley ${ }^{2}$
}

\begin{abstract}
Designers have become aware of the importance of creating strong emotional experiences intertwined with new tangible products for the past decade, however an increased interest from firms has emerged in developing new service and business models as complimentary forms of emotion-driven innovation. This interdisciplinary study draws from the psychological sciences - theory of emotion - and the management sciences - business model literature to introduce this new innovation agenda. The term visceral hedonic rhetoric (VHR) is defined as the properties of a product, (and in this paper service and business model extensions) that persuasively induce the pursuit of pleasure at an instinctual level of cognition. This research paper lays the foundation for VHR beyond a product setting, presenting the results from an empirical study where organizations explored the possibilities for VHR in the context of their business. The results found that firms currently believe VHR is perceived in either their product and/or services they provide. Implications suggest shifting perspective surrounding the use of VHR across a firm's business model design in order to influence the outcomes of their product and/or service design, resulting in an overall stronger emotional connection with the customer.
\end{abstract}

Keywords: visceral hedonic rhetoric, emotional design, business innovation, service design, business model design.

\section{INTRODUCTION}

Studies have found that $80 \%$ of an individual's life is consumed by emotions while the other $20 \%$ is intellect (Lough, 2006). Damasio (1999) states that $85 \%$ of thought, emotion and learning occur in the subconscious mind, beyond the reach of rationalization or reasoning. This could be due to the emotional part of the brain being larger, and therefore tends to dominate over the rational brain and control the thought process of individuals (Abraham,

1 Karla Straker, Queensland University of Technology, Queensland, Australia, Tel. +61731389471, e-mail: k.straker@qut. edu.au.

2 Cara Wrigley, Dr, Senior Lecture, Design-led Innovation, Queensland University of Technology, 2 George St, Brisbane, Australia, Tel. +61731389471, e-mail: cara.wrigley@qut.edu.au. 
1999; Kunnanatt, 2004). The emotional connection between a customer and product is one of complicated behaviour and multifaceted reasoning, yet is powerful enough to entice customers to choose one product over another (Forlizzi, Disalvo and Hannington, 2000). This in turn has led to designers designing products that target customer emotions, specifically with the aim to induce a strong user-product attachment (Desmet, 2002). According to Norman (2004) the field of design and emotion comprises of elaborate human behaviours, involving emotional processing, immersed in this is the level of visceral cognition (Norman, 2004). Product designers have become aware of the importance of creating strong emotional experiences intertwined with new tangible products for the past decade (Jordan, 2000; Norman, 2004). However, as current as this field is, a lack of theoretical precision exists in the instalment of emotional design (Forlizzi, Disalvo and Hannington, 2000) beyond product innovation alone.

The term visceral hedonic rhetoric (VHR) is defined as the properties of a product (and proposed in this paper, services and business model design) that persuasively induces the pursuit of pleasure at an instinctual level of cognition (Wrigley, 2013). Emotions can influence the success in product innovation by customer attraction and purchase decisions. An increasing interest from research and industry has emerged in developing new services and business models as complimentary forms of innovation in order to create emotional connections with customers. Even though designers have considered the role of emotions in products and developing customer services, the design of business models that incorporate emotions is not yet well understood. However, when generating new products and or services, the design of a business model is just as important for success due to creating a desired response from the customer. As consumers' emotions have a significant influence on purchase and consumption decisions for a wide variety of products, emotional needs lay at the foundation for consumers making purchase decisions. Hill (2010) also expresses that selling consumers on what they already believe and feel is easier than changing that persons' belief. O'Shaughnessy and O'Shaughnessy (2003) argue that emotions will always be a factor in consumer decision-making and that consumers constantly make decisions surrounding the selection, consumption and disposal of products. Therefore, appealing to a prospective consumer's emotional needs is the key action leading to the purchase of a product.

An investigation of VHR in response to a variety of products, services and business models was conducted with seven Australian small to medium enterprises and four multi-national firms to understand their views of what VHR meant in the context of their businesses and how they could perceive it adding value in the future. Semi-structured interviews were conducted with 
company employees after an introduction workshop to define what VHR was as a concept. The research of VHR is of vital importance not only to the design discipline but also to business model design innovation due to the opportunity to create powerful emotional connections between consumers and companies.

\section{Emotional design}

Emotional design is described as the emotional connection humans have to everyday objects and products (Norman, 2004). There has been a steady growth in design and emotion research since its' emergence in 1999, which has focused on understanding the emotions elicited during the use of a product and developing tools and techniques that facilitate an emotion-cantered design process (Desmet, 2002). Noteworthy authors within this field include Norman (2002), Desmet (2002) and Jordan (2000) who have investigated a range of areas including the cognitive process, the design of products and the design of the user's experience and interaction with a product. In Norman's (2004) research it is questioned why washing and polishing your car make it drive better and explores why attractive objects provide the sometimes illusory, sometimes real, effect of superior function. A review of the body of research in the area of design and emotion reveal a general consensus that an individual reacts to the world through his or her emotions, and that stimuli such as arousal, action tendency and subjective feeling (pleasant or unpleasant) evoke emotions in all individuals (Weerdesteijn, Desmet and Gielen, 2004). Additionally, emotions are implicated into all aspects of daily life (e.g. mood, cognition, behaviour, attention, perception and memory) and influence everyday activities and interaction between people, products and the environment.

\section{Visceral hedonic rhetoric (VHR)}

Visceral hedonic rhetoric originated form the combination of visceral design, consumer hedonics, and product rhetoric (conglomerate VHR) areas of research. Norman (2004) describes visceral design as the cognitive examination of immediate responses enabling users to react to visual and other sensory aspects of a product before considerable contact transpires. This is an experience that consumers are powerless to dictate and are often unaware of its occurrence as it is embossed in the unconscious psyche of the user (Norman, 2004). Many authorities have tried to define visceral design due to its use in many different contexts and across a broad scale and spectrum (Loewenstein, 1996). From the reviewed literature, the information regarding visceral design is fairly broad and no case study has been found 
that focuses entirely on visceral design or visceral hedonics. Add this to the apparent lack of research linking visceral hedonic responses to products and their consequent design properties, the need for understanding in this subject becomes quite considerable.

Hedonics can be defined as the branch of psychology that studies the mind's pleasant and unpleasant sensations and has been identified as anything relating to the pursuit of pleasure (Hirschman and Holbrok, 1982). Hedonics is also significantly influential to consumers. The customers' choices and decisions are made to purchase a product for their enjoyment, pleasure and excitement is derived from the emotional design of the product (Barrett, Mesquita, Ochsner and Gross, 2007). While consumers have often reported wanting functional or tangible attributes when purchasing products, there is also a demand for a hedonic or satisfying emotional response and experience when using a product. Hedonic behaviour in consumers relates to aspects of the product purchase and handling experience, and to the multi-sensory, fantasy and emotive aspects of product usage (Hirschman and Holbrok, 1982). Inevitably hedonics is important to a product's success and is considered in the design industry as the pursuit of pleasurable design (Porter, Chiber and Porter, 2004). From the literature examined there remains a need to separate and compare responses and to determine their causes as this still presents a significant gap in the field of hedonics. It is an issue that must be thoroughly addressed if any significant emotional contribution to design is to be made (Jordan, 2000).

Throughout history, rhetoric has been defined as the art of speaking well or the art of persuasive verbal communication. Over the years it has developed interdisciplinary associations with the common goal of effective communication (Erlhoff and Marshall, 2007). Today, rhetoric is undergoing a new era of research and development, with designers helping to shape it to meet contemporary demands (Kaufer and Butler, 1996). If designers can benefit from rhetorical insights, then design can continue to influence and form society through its persuasive assertions. Uncovering what designers need to discover is an entirely new aspect of demonstrative rhetoric that will significantly affect the understanding of product influence in the future. Product rhetoric provides literature with persuasive product design properties and focuses on the features that enable products to communicate convincingly. In relation to visceral hedonics, it grounds the study in the field of product design.

Wrigley $(2013$, p.43) revealed the gap of the combination of VHR where it was defined as "properties of a product that persuasively elicit the pursuit of pleasure through an instinctual level of cognition". In this definition, "properties of a product" refer to a product's physical attributes, such as 
size, material, colour, smell, form and other distinguishing features. It is the proposition of this paper that a combination of visceral design, consumer hedonics and product rhetoric, can assist in the design of novel products, services and business models, which are required for more competitive business strategies.

\section{Visceral hedonic rhetoric beyond products}

Visceral hedonic rhetoric has been contextualised through the use of interactive consumer products (Wrigley, 2011). However, pursuing VHR throughout services and business models is needed to sustaining an emotional connection with consumers. There is an abundance of research into design and emotion outlining many important findings and implications for product design, but much less on services, and even less or next to none on business models (Bucolo and Wrigley, 2012). Goddin, Varnes, van der Hoven and Koners (2012) explain that companies that provide services, rather than tangible products face the challenge in acquiring insight into customer's needs, due to services intangibility, inseparability and heterogeneity (each service employee and each customer interaction is different) (Johnson, Christensen and Kagermann, 2008).

Beyond product design, authorities have established and explored emotion through various fields such as branding and customer loyalty (Hill, 2010; Robinette, 2003), marketing (O'Shaughnessy \& O'Shaughnessy, 2003) and customer services (Roberts, 2005). The interaction a company has with a customer can all affect a customer's emotion (Roberts, 2005), this expands from a customer visiting a store or web site to employee interaction and communications to loyalty programs. Robinette $(2003$, p.4) believes that "in every encounter there's an opportunity to meet a need and make an emotional connection" with the customer. Robinette (2003, p. 4) discusses emotional marketing, which is the "wide pursuit of a sustainable connection that makes customers feel valued and cared for that they will go out of their way to be loyal". Robinette (2003) elevates emotion to the strategic level, recognising its importance in creating or strengthening a relevant brand identity and managing a customer's experience. There are many examples of companies who have been successful at emotional marketing, such as, Hallmark, Fed-ex, Walgreens pharmacy and Starbucks (Robinette, Brand, Lenz and Hall, 2000), due to them exceling in providing excellent customer service. Roberts (2005) believes brands can be transformed into Lovemarks that people fall in love with. In order for a brand to be a Lovemark it needs to connect companies, their customers and brand to create loyalty beyond reason as they are owned and used by customer who love them (Roberts, 2005). Caring is essential to 
loyalty therefore companies must go beyond seeking customer satisfaction to showing customers they genuinely care (Roberts, 2005; Robinette, 2003).

Hill (2010, p.226) explains, "Nothing is more emotional for consumers or dangerous for companies than an unsatisfied customer". The interaction with a customer through visiting a store or web site, employee contacts, communications and loyalty programs can all affect a customer's emotion (Roberts, 2005). Trust and emotion become important mediators in the service recovery process (DeWitt, Nguyen and Marshall, 2008). Therefore, the role the salesperson plays is critical in communicating emotional brand values (Lynch and De Chernatony, 2004), however is often an overlooked aspect in business management and strategy.

Norman (2004) states "everything that we do, everything we think is tinged with emotion" and it is for this reason that companies need look beyond product offerings for understanding the real needs of consumers (Crossley, 2002). In a study involving 23,000 American consumers, it was concluded that emotions are twice as important as facts in the decision buying process (Morris, Woo, Geason and Kim, 2002). The creation of value through emotion is not only important in products and service but also throughout the company. According to Teece $(2010$, p.172) the core of a business model design is the way in which a company delivers "value to customers, entices customers to pay for value, and converts those payments to profit". It therefore reflects management's hypothesis about what customers want, how they want it, and how the enterprise can organize to best meet those needs (Teece, 2010). The purpose and key aspects of a business model are often agreed upon through literature, as the notion of value, either as value proposition, value stream or value chain (Chesbrough and Rosenbloom, 2002; Osterwalder and Pigneur, 2010; Zott, Amit and Massa, 2010). Zott, Amit and Massa (2010) explain that a primary characteristic of a new business model is the creation and capture of value to occur in the value network. This value network can include suppliers, partners, branding, service model, funding, distribution channels and activities (Bucolo and Wrigley, 2012; Zott, Amit and Massa, 2010). The notion of value creation is an impacting driver in a business model, however the role of emotion throughout a business value chain or business model design is not yet well understood. However, in the branding arena emotions can represent a measure of attachment that a customer has to the business/brand, reflecting the likelihood of engagement in the experience, leading to recurring purchase (Ghodeswar, 2008). Keller and Lehmann (2003) propose that the customer mind set is the key driver of brand performance. If the customer is engaged in the experience and brand over recurring engagements, it has the potential to have a significant effect on the perception of the brand (Verhoef et al., 2009). However, with the 
growing amount of product, service offerings, companies are faced with the challenge to unify their brand value across multiple fronts in a way that is consistent in engaging their customers.

\section{A strategic approach}

The evidence presented suggests that VRH has been studied predominately from a product design predisposition while research is yet to be conducted from a business model viewpoint. Norman (2010, p.40) states "innovation is a systems issue; it is not about product or process, but the entire system". Teece (2010, p.3) also expresses "without a well-developed business model, innovators will fail to either deliver or to capture value from their innovations". Business models can be described as corporate blueprints for how to conduct business and generate revenue (Osterwalder and Pigneur, 2010). In Osterwalder's business model canvas, the nine elements are resources, activities, partners, value proposition, customers, delivery channels, customer relationships, cost structure, and revenue stream. The purpose of a business model is to understand what value is provided to the customer (Osterwalder and Pigneur, 2010), which products or services are then designed to produce a proposition of value to customers (Demil and Lecocq, 2010). A business model of a firm constitutes multiple value creation processes, which is partly; branding, service model, funding, distribution and activities (Bucolo and Wrigley, 2012), there is a need to better understand the relationship between these elements, emotions and the customer. Bucolo and Wrigley (2012) suggest the creation of an emotional business model to encouraged firms to firstly identify and then better understand the needs of their stakeholders. The results or outcome of this emotion business model are opportunities that clearly link the functional aspects (product or service) of the business model to emotion aspects of the customer. Focusing explicitly on a firm's capacity to build emotional connections across their value chain ensures this. The successful application of this can be a powerful competitive advantage as it's almost impossible to replicate (Robinette, 2003). As any competitor can match functional and technical characteristics, however, they cannot easily match the emotional experience promised (Lynch and De Chernatony, 2004). Hill (2010) explains that all too often companies choose what their product or service is over who their customer is, for competitive advantage. Bucolo and Wrigley (2012) suggest the creation of an emotional business model to encouraged firms to firstly identify and then better understand the needs of their stakeholders. The results or outcome of this emotion business model are opportunities that clearly link the functional aspects (product or service) of the business model to emotion aspects of the customer and internal operations. 
An example of an emotional business model can be demonstrated through the comparison of Apple and Samsung mobile phones. Both are suitable (aesthetically pleasing and functional) designs at a product level, however Apple continues the notion of emotion throughout its' entire business model. The Apple brand is a Lovemark, it is a brand that consumers love because the branding or experience felt is consistent from the product, to the packaging, to the marketing messages and continues to the experience of walking into an Apple retail store. While Samsung can compete on a product level, it is unable to provide the same customer experience as Apple in western markets. Focusing explicitly on a firm's capacity to build emotional connections across their value chain can ensure the creation of an emotional business model. Lynch and De Chernatony (2004) explain that attention needs to be given to (company) values to ensure that they are communicated not only externally but also within the organisation. As consumers buy brands that provide emotional reinforcement and are aligned with core beliefs that are built upon core emotions (Hill, 2010). The successful application of this can be a powerful competitive advantage as it is almost impossible to replicate (Robinette, 2003). The aim of this research was to understand this further by exploring the current perspective of VHR responses in the context of a range of businesses. In addition this research aims to present new insights and understandings of VHR for the design of future products, services and business models, with a variety of visceral hedonic responses explored.

\section{Research approach}

Participants of this study were firm representatives from four multi-national companies and seven Australian small to medium enterprises (SMEs) firms from a variety of different industries, including product manufactures, financial institution to utility providers (Table1). Specifically, this paper reports the findings on VHR within a larger research project that traced the process and progress of re-framing design more strategically in their organisation.

Table 1. Participant and organization summary

\begin{tabular}{llll}
\hline No & Industry Sector & Size & Firm Participants \\
\hline 1 & Transportation & Multi-National & Marketing Manger \\
2 & Healthcare & Multi-National & Marketing Manger \\
3 & Infrastructure & Multi-National & R\&D Manger \\
4 & Insurance & Multi-National & Product and Service Manager \\
5 & Manufacturing & SME & Sale Manager \\
6 & Manufacturing & SME & Product Manger
\end{tabular}




\begin{tabular}{llll}
7 & Manufacturing & SME & Brand Strategist \\
8 & Finance and banking & SME & Product Manger \\
9 & Manufacturing & SME & Director \\
10 & Manufacturing & SME & Engineering Manger \\
11 & Manufacturing & SME & R\&D Manager \\
\hline
\end{tabular}

\section{Method}

All participants (identified in Table 1) took part in a short workshop before the one on one interview was conducted. The workshop gave an introduction to visceral design, consumer hedonics and product rhetoric. Participants were able to ask questions to clarify any issues on their understanding of VHR before the interview. Data was collected through semi-structured interviews in which participants were asked a set of questions on:

1) How they thought VHR currently fits in their company. This included asking where they positioned it (operational or strategic).

2) Their perceptions on the importance of visceral, hedonic and rhetoric in regards to the company.

3) What emotions they think and what they want their customer to feel in relation to their products, services and overall company.

The eleven interviews sought to gain company perspectives from employee instead of their customers. Their initial expectations, perceptions and the value of VHR were explored. The semi-structured interviews were conducted in a face-to-face setting lasting approximately sixty minutes each. Responses were recorded and transcribed with participant consent (Myers, 2009). Investigator triangulation was utilized by each researcher conducting the interviews (Collins, 2010). Transcripts were then analyzed using a thematic approach (Braun and Clarke, 2006; Miles and Huberman, 1994) to uncover consistent themes. Identifiable firm intellectual property was excluded from the analysis for ethical purposes. As this data did not align to the scope of the study, exclusion has not impacted the reported findings. The analysis was completed by the research team using grounded theory, first, to identify codes, second, to group codes into similar concepts and third, to group comparable concepts to generate theory (Miles and Huberman, 1994). The use of analysis triangulation allowed each researcher to both analyze the results separately and amalgamate data to validate findings.

The limitations of this research need to be acknowledged, with further research required to develop an extensive and deeper understanding of VHR in products, services and business models. The smaller sample size is due to strict time constraints and the time intensive methodology and analyses approach. This does limit the ability to generalize results, however, provides 
richer, in-depth information, which the authors believe to be critical in achieving a deeper understanding of VHR in a product, service and business model design context. This research was conducted with employees of the respective firms to understand the emotional perceptions of their products, services and business models. A limitation of this approach is not gaining insights from customers of the target group of products and services. Employee views may be swayed by information asymmetries and group dynamics.

\section{RESULTS}

Results reveal how VHR was perceived in the context of a firm and have been separated in the perceived categories (i) Product (ii) Service (iii) Business model. Table 2 illustrates some sample responses to demonstrate the categorisation.

Table 2. Example participant responses

\begin{tabular}{|c|c|c|c|}
\hline & Product & Service & Business Model \\
\hline Visceral & $\begin{array}{l}\text { "I can't have this meal } \\
\text { without this product" }\end{array}$ & $\begin{array}{l}\text { "Reliability is KING and we } \\
\text { do everything to sort out } \\
\text { loss of service" }\end{array}$ & $\begin{array}{l}\text { "Brand choice on } \\
\text { aesthetic of product" }\end{array}$ \\
\hline Hedonic & $\begin{array}{l}\text { "Make a decision } \\
\text { based on the physical } \\
\text { appearance of the } \\
\text { luminaries" }\end{array}$ & $\begin{array}{l}\text { "Displeasure being } \\
\text { 'sterilised' through } \\
\text { security" }\end{array}$ & $\begin{array}{l}\text { "Nostalgic- a brand I grew } \\
\text { up with" }\end{array}$ \\
\hline Rhetoric & $\begin{array}{l}\text { "This is for mostly a safety } \\
\text { requirement"" }\end{array}$ & $\begin{array}{l}\text { "Crucial part of the } \\
\text { installation process" }\end{array}$ & $\begin{array}{l}\text { "Security, trusted } \\
\text { Australian, plan for goals } \\
\text { future" }\end{array}$ \\
\hline VHR & $\begin{array}{l}\text { "Currently very little } \\
\text { consideration is given } \\
\text { to the user's emotional } \\
\text { experience when using the } \\
\text { product" }\end{array}$ & $\begin{array}{l}\text { "In this case VHR } \\
\text { essentially means making } \\
\text { the sales/ installation } \\
\text { process as easy as } \\
\text { possible" }\end{array}$ & $\begin{array}{l}\text { "I'm not entirely sure how } \\
\text { to apply VHR to business } \\
\text { strategy" }\end{array}$ \\
\hline
\end{tabular}

\section{The applicability of VHR}

When asked about VHR in the context of their firms, two participant's responses included: "VHR is essentially an ideal that would be nice to consider. The importance of emotion and user experience is somewhat understood, however it is currently an afterthought at best" and "VHR- we try to do this we know we have to, we struggle with it, it sits behind every other product requirement". The others firm representatives responded by associating the value of VHR strongly with one aspect of their company. A product-manufacturing firm remarked, "Since (our company) produces products to be used by people, I 
think VHR is most important to the product itself in order to create an emotional connection between the end user and product". A product manufacturing firm which provides an installation service commented, "customers and installers, consideration is given to the service (our company) can provide to them". While a business-to-business firm stated, "Business - we need to make businesses want to do business with us, they bring the customers".

\section{Product}

Overall the participants found it easiest responding to the visceral and hedonic responses through their products. Immediate (visceral) responses included; "I can't have this meal without this product" and "Customers make a decision based on the physical appearance of the luminaries". Some participants could state clearly how VHR could or is present in their product, while others stating it not to be a focus at all. One participant believed it to be only present in the product as it was not considered in other aspect of their business, "It is most important through the product, but this is currently the situation merely because it is the only context where these factors are being considered". A different firm understood what their organisations value proposition was however it was not reflected in practice, "the company's value proposition for the end user is centered around lifestyle, which is inherently emotional, however this is not really reflected in the design process". While another firm commented that the product was not a focus of their firm or VHR associated with it, "Currently very little consideration is given to the user's emotional experience when using the product... this is not the focus".

\section{Service}

The important of VHR became very apparent in service-based companies through the installation and maintenance process. Rhetoric was mostly associated with this area of the firm, "Product rhetoric is a crucial part of the installation process... However the end user will not be harvesting any benefits of good rhetoric". Many firms made the connection of VHR through the service of installation and maintenance their firms provided for their product. A participant associated VHR not with their customers but with the firm's employees, "in this case VHR essentially means making the sales/ installation process as easy as possible". However, in another firm that did not provide a tangible product but a service, that representative commented, "VHR is more important to (our company) through service, this is what people see, the guys fixing the issues as they arise and they save the day". Within the same firm it was said when this service cannot be supplied, "then the VHR is possibly very clear from the customer, it is not here and I am not happy". 


\section{Business model design - branding}

All participants had a harder time finding the VHR association with their overall business model, with a participant responding; "I'm not entirely sure how to apply VHR to business strategy". A common association of visceral and hedonic was through particular elements of a business model, the most common being branding. One participant responded, "It's a brand I grew up with" and in which he explain that it resonated with a lot of customers as nostalgia. Another response included "brand, lack of attachment" explaining that currently the firm representative feels customer have no attachment with their brand. The third connection of brand was through the choice of aesthetic products the firm offered its customers. Another element of the business model design that other firm representatives touch upon was their value proposition. Many believed that customers connected with their firm through what it meant to them. Words used to represent these values included security, protection, nostalgic, trusted and reliable. The last connection to a business model design element was included key partners, "partnership as power generation and storage becomes decentralized". Overall a firm representative commented that finding out more insights about VHR and its position within in their firm, "would make a great and crucial impact on the business model itself, which could lead to a positive change in the physical products".

\section{Discussion}

The research of VHR is of vital importance to the design of products, services and business model designs due to the possibility of creating powerful emotional connections between customers and companies. However, the results found that how firms perceived the applicability of VHR many admitted they struggled to execute this correctly. Results also related strongly to the type of business they were in. Such as in the product-manufacturing firms VHR was predominately positioned at the product level, while service based firms positioned it within their customer service departments and systems. It could be argued that this is due to the intangibility of services and therefore the firm perceived it to be less of a visceral response and more emphasis was placed on hedonistic experience. This highlights the imperative nature of the conglomerate area of VHR as visceral responses occur also in intangible services. Firms in product manufacturing particularly had trouble articulating how it could fit into services or the business model design of their firms. This could be referred to as a visceral response as products are tangible objects, and allow for an immediate connection to be made with an emotion. While firms who provide services and products found that VHR was easily related, 
not to the customer but through the employees of the firms providing maintenance or installation. In these cases VHR became a large influence in responses from participants as communication of providing how to install or maintain products became the focal point. This was perhaps understood as rhetoric - an element that aims to provide successful communication. However, in terms of VHR, rhetoric is associated with the goal of providing strategically effective communication, as in having a persuasive assertion.

Firms who provide a service faced the challenge in acquiring insight into customer needs (Goffin, Varnes, Van der Hoven and Koners, 2012). Due to service intangibility, the service experience can vary due to inconsistencies such as interaction with service employees (Johnson, Christensen and Kagermann, 2008). DeWitt, Nguyen, Marshall (2008) respond to how service failure can influence a customers' emotional state. In a participant's response it was discussed that the failure of the service provided a high degree of emotional response from customers, but when the service was stable there was little response from customers. However, the participant commented that the firm has the opportunity to incorporate VHR when a failure occurs. In this company the service response teams were seen as heroes, changing the emotions customers associate with the service failure. DeWitt, Nguyen, Marshall (2008) believe that influencing a customer's emotional response is an important mediator in the service recovery process.

As discussed the use of a tangible product made it easier for respondents to make a connection with a product vertical, however, in relation to the business model design, many emotional connections can be made with all nine elements of the business model. Interview participants related visceral, hedonic and rhetoric to the value proposition, key partners and channels in their business models. The strongest was through branding. Authorities (DeWitt, Nguyen, Marshall, 2008; O'Saughnessy and O'Saughnessy, 2003; Roberts, 2005; Robinette, 2003) discuss the emotional connection through branding as a way for creating customer loyalty. One participant spoke of his own personal nostalgia towards the firm's brand, which could be explored through VHR as a way to create a strong emotional connection with customers. As using emotions as a strategy is a possible solution to sustaining customers or creating new customer through positive product or service experiences. None of the participants commented on the experience of their customers, overall emotions were only related to the product or services. While consumers have often reported on wanting functional or tangible attributes when purchasing products, there is also a demand for a hedonic or satisfying emotional response and experience when using a product.

In order to make an emotional connection with a customer, a firm must first be able to associate emotions into their business model. Doing 
so involves shifting a firm's immediate response on VHR from products or services into a business model focus. Focusing explicitly on a firm's capacity to build emotional connections across their value chain will provide powerful competitive advantage as it almost impossible to replicate (Robinette, 2003). However, this requires a deeper exploration of a firm's business model. It was found that firms struggled to articulate the emotional aspects of their firms, therefore tools and methods such as Value Star Method (Robinette, 2003), Lovemark (Roberts, 2005) and Emotional Business Modeling (Bucolo and Wrigley, 2012) should be utilised to understand their customer and value proposition.

\section{CONCLUSION AND FUTURE RESEARCH}

Designers have become aware of the importance of creating strong emotional experiences intertwined with new tangible products for the past decade, this was seen in the results the perceived role of VHR had been associated highly with products. However, it is the view of the authors that there must be a common relationship of VHR through the design of products, services and business models. The primary motivation for this paper was to explore VHR and its role beyond product design. It is the proposition of this paper that a combination of the visceral design, consumer hedonics, and product rhetoric categories, can assist in the innovation process within an organisation. The results show that firm representatives currently believe VHR is evident in either their product and/or services. There remains a gap as to how businesses are able to undertake business model design through the understanding and integration of VHR. Further research will therefore be conducted to investigate these propositions in depth to gain an understanding how the integration of VHR can facilitate business model design. A shift in perspective of the use of VHR across all the elements of a firm's business model is suggested to influence the outcomes of their product and/or service they provide to have a stronger emotional connection with their customers. As $80 \%$ of a consumer's life is consumed by emotions while the other $20 \%$ is intellect (Lough, 2006), generating new products, services or business strategies it is important to consider emotions to create the desired response from the consumer.

There is rich research into design and emotion that outlines tools and methods for designing for emotional experiences, however, less is known in relation to the integration of VHR through business models. Implementing VHR within the creation and development of a business model could facilitate business innovation through the expansion of consideration of customer emotions beyond just a product offering. However, to achieve this, the 
authors propose a series of iterative experiments instead of implementing a linear approach. Rather than writing a static business model that have little or no basis in reality, an emotional approach requires a series of prototyped business models to be tested and validated with customers. The objectives of this research were to explore VHR responses within a business context while the future conclusions of this research present new insights and understandings of VHR for the design of future products, services and business models, with a variety of visceral hedonic responses. This will not only assist the immediate industry of product design but the wider design and business innovation domain. It is anticipated to offer a greater perspective in the use of VHR as well as avenues for further investigations.

\section{References}

Abraham, R. (1999). Emotional intelligence in organizations: A conceptualization. Genetic, Social, and General Psychology. Monographs, 125, 209.

Barrett, L., Mesquita, B., Ochsner, K., \& Gross, J. (2007). The Experience of Emotion. Annual Review of Psychology, 5(8), 373-403.

Braun, V., \& Clarke, V. (2006). Using thematic analysis in psychology. Qualitative Research in Psychology, 3(2), 77-101.

Bucolo, S., \& Wrigley, C. (2012). Using a design led approach to emotional business modelling. In Leading Innovation through Design: Proceedings of the DMI 2012 International Research Conference, Boston, MA, USA, 323-333.

Chesbrough, H., \& Rosenbloom, R. (2002). The role of the business model in capturing value from innovation: evidence from Xerox Corporation's technology spin off companies. Industrial and Corporate Change, 11(3), 529-555.

Crossley, L. (2002). Building Emotions in Design. The Design Journal, 6(3),3545.

Damasio, A. (1999). The Feeling of What Happens: Body and Emotion in the Making of Consciousness. Harcourt: New York.

Demil, B., \& Lecocq, X. (2010). Business Model Evolution: In Search of Dynamic Consistency. Long Range Planning, 43(2-3), 227-246.

Desmet, P. (2002). Designing Emotions. Delft: Delft University of Technology.

DeWitt, T., Nguyen, D. T., \& Marshall, R. (2008). Exploring Customer Loyalty Following Service Recovery: The Mediating Effects of Trust and Emotions. Journal of Service Research, 10(3), 269-281.

Erlhoff, M., \& Marshall, T. (2007). Design Dictionary. Birkhauser.

Forlizzi, J., Disalvo, C., \& Hanington, B. (2000). On the relationship between emotion, experience and the design of new products. The Design Journal, $6(2), 29-38$. 
Ghodeswar, B. (2008). Building brand identity in Competitive markets: A conceptual model. Journal of Product and Brand Management, 17(1), 4-12.

Goffin, K., Varnes, C. J., Van der Hoven, C., \& Koners, U. (2012). Beyond the Voice of the Customer: Ethnographic Market Research. ResearchTechnology Management, 55(4), 45-54.

Hill, D. (2010). Emotionomics: Leveraging Emotions for Business Success. Kogan Page: London.

Hirschman, E., \& Holbrok, M. (1982). Hedonic Consumption: Emerging Concepts, Methods and Propositions. Journal of Marketing, 46(3), 92101.

Johnson, M. W., Christensen, C. M., \& Kagermann, H. (2008). Reinventing Your Business Model. Harvard Business Review, (December), 86(12), 57-68.

Jordan, P. (2000). Designing Pleasurable Products. Taylor and Francis: New York.

Kaufer, D., \& Butler, B. (1996). Rhetoric and the art of design. Lawrence Erlbaum Associates Publishers: New Jersery.

Keller, K. \& Lehmann, D. (2003). How Do Brands Create Value? Marketing Management, 12(3), 26-31.

Kunnanatt, J. T. (2004). Emotional intelligence: The new science of interpersonal effectiveness. Human Resource Development Quarterly, 15(4), 489-495.

Loewenstein, G. (1996). Out of Control: Visceral Influences on Behaviour. Organizational Behaviour and Human Decision Process, 65(3), 272-292.

Lough, W. (2006). Once more with feeling. Knoxville: University of Tennessee. Lynch, J., \& De Chernatony, L. (2004). The power of emotion: Brand communication in business-to-business markets. Journal of Brand Management, 11(5), 403-419.

Magretta, J. (2002). Why business models matter. Harvard Business Review, 80(5), 86-92.

Morris, J., Woo, C., Geason, J. A., \& Kim, J. (2002). The Power of Affect: Predicting Intention. Journal of Advertising Research, 42(3), 7-17.

Norman, D. (2002). The design of everyday things. Basic Books: New York.

Norman, D. (2004). Emotional Design. Basic Books: New York.

Norman, D. (2010). Technology first, Needs last: The research-Product Gulf. Interactions, 17(2), 38-42.

O'Shaughnessy, J., \& O'Shaughnessy, N. J. (2003). The Marketing Power of Emotion. Oxford University Press: New York.

Osterwalder, A., \& Pigneur, Y. (2010). Business Model Generation: A Handbook for Visionaries, Game Changers, and Challengers. John Wiley \& Sons Ltd: UK.

Porter, S., Chibber, S., \& Porter, J. (2004). Towards an understanding of pleasure in product design. In Design and Emotion. CRC Press, 342-347.

Roberts, K. (2005). Lovemarks. PowerHouse Books: UK. 
Robinette, S., Brand, C., Lenz,V., \& Hall, D. (2000), Emotion Marketing: The Hallmark Way of Winning Customers For Life. McGraw-Hill: New York. Robinette, S. (2003). Emotion marketing. Telephony, (19), 40-41.

Teece, D. J. (2010). Business Models, Business Strategy and Innovation. Long Range Planning, 43(2-3), 172-194.

Weerdesteijn, J. M. W., Desmet, P. M. A., \& Gielen, M. A. 2005. Moving Design: To Design Emotion through Movement. The Design Journal 8(1), 28-40.

Wrigley, C. (2011). Visceral Hedonic Rhetoric. 1-224 Available at: http:// eprints.qut.edu.au/46040/ [Accessed March 24, 2013].

Wrigley, C. (2013). Design Dialogue: The Visceral Hedonic Rhetoric Framework. Design Issues, 29(2), 82-95.

Verhoef, P., Lemon, K., Parasuraman, A., Roggeveen, A., Tsiros, M., \& Schlesinger, L. A. (2009). Customer Experience Creation: Determinants, Dynamics and Management Strategies. Journal of Retailing, 85(1), 3141.

Zott, C., Amit, R., \& Massa, L. (2010). The Business Model: Theoretical Roots, Recent Developments, and Future Research (Working Paper). IESE Business School, University of Navarra.

\begin{abstract}
Abstrakt (in Polish)
Projektanci staja się świadomi znaczenia tworzenia silnych doznań emocjonalnych powiqzanych z nowymi produktami materialnymi w ostatnim dziesięcioleciu. Jednak, również ze strony firm, pojawiło się zwiększone zainteresowanie w opracowywaniu nowych usług i modeli biznesowych, jako uzupełniajqcych innowacyjnych form opartych na emocjach. To interdyscyplinarne badanie czerpie z nauk psychologicznych teorii emocji - i nauk o zarzqdzaniu - literatury modelu biznesowego do wprowadzenia nowego programu innowacyjnego. Termin VHR - retoryka dogłębnego hedonizmu jest zdefiniowany jako właściwości produktu (w tej pracy rozszerzenie usług i modelu biznesu), który przekonujqco skłania do dqżenia do przyjemności na instynktownym poziomie poznania. Ta praca stanowi podstawę dla VHR poza domyślnym środowiskiem produktu, prezentujq̨c wyniki badań empirycznych, które organizacje przeprowadziły badajqc możliwości zastosowania VHR w kontekście ich działalności. Stwierdzono, że firmy obecnie wierzq, że VHR jest postrzegane albo w ich produkcie i/ lub w usługach, które świadczq. W konsekwencji, sugeruje to przeniesienie perspektywy wokół korzystania z VHR w konstrukcji modelu biznesowego danej firmy, w celu wpływania na wyniki swoich produktów i / lub projektowania usług, co prowadzi do ogólnego silniejszego zwiq̨zu emocjonalnego z klientem.
\end{abstract}

Słowa kluczowe: VHR, projektowanie emocjonalne, innowacje biznesowe, tworzenia usług, projektowanie modelu biznesowego.

\title{
Biographical notes
}

Karla Straker is a graduate of Industrial Design at the Queensland University of Technology and is currently completing her PhD. Her research is cross- 
faculty, engaging with industry and academics across the fields of design, business and information systems. Karla's research is focused on working with companies to understanding customer emotions as a way to design engaging interactions via technology.

Dr Cara Wrigley is a senior lecturer in the field of Design-led Innovation (DLI). Building on her solid practical industry experience and combined with her scholarly expertise in emotional design, she is actively researching the value that design holds in business - specifically through the creation of strategies to design business models which lead to emotive customer engagement. She currently directs the Queensland University of Technology's DLI Research Lab, placing postgraduate researchers within Australian businesses. Cara has presented and published widely in the field of design-led innovation and currently leading several initiatives to contribute to both industry and academia on the value of design to business. 